\title{
DETERMINANTS OF THE AWARENESS AND USE OF ELECTRONIC INFORMATION SYSTEMS: EVIDENCE FROM FARMERS IN BURKINA FASO
}

\author{
Achille A. DIENDERE
}

\author{
Address: \\ University Ouaga II, Department of Economics and Management, Burkina Faso, 12 BP 417 Ouaga 12. \\ Corresponding author: $\underline{\text { hchille@yahoo.fr }}$
}

\begin{abstract}
The use of information systems using mobile phone support is important in agriculture in terms of generating efficiencies in production and improving farmers' incomes. In Burkina Faso, despite the increasing spread of a wide variety of agricultural information via mobile phones since the 2000s, few farmers have adopted such an electronic information system. This research aims to empirically analyse the factors that influence the awareness and use of electronic information systems by producers. Primary data were collected from a sample of 210 grain producers and analysed using descriptive statistics and a logit sequential model. Descriptive statistics indicated that farmers interviewed had an unmet need for timely access to relevant, reliable, continuously available, and unfragmented information. The econometric results suggest that a high number of years of schooling for the head of household, regular contact with extension agents and technical assistance from market information systems (MIS) management structures influence awareness of electronic information systems. With regard to the actual use of the services offered by these information systems, the presence of educated members in the household, the size of the farm, the perceived relevance of non-commercial benefits derived from the information disseminated and access to agricultural financing appear as significant determinants. These results have required more targeted public policies.
\end{abstract}

Keywords: adoption, electronic information system, agricultural information, farmers, Burkina Faso JEL: Q10, Q12, Q13, Q16

\section{INTRODUCTION}

Market information systems (MIS) are one of the most significant innovations revolutionizing information technology in the agricultural sector (Diekmann et al., 2009; Minten al., 2012; Subervie and Galtier, 2012; Tadesse and Bahiigwa, 2015; Beza et al., 2018). These systems are devices intended to collect, process and disseminate information on the situation and dynamics of agricultural markets to economic agents (public and, especially, private actors, such as agricultural producers, traders and consumers). The information disseminated is supposed to reinforce the transparency of markets and help the actors in their decisions about production and marketing. MIS generally disseminate information using different types of support: rural radios, billboards, print media (newspapers, newsletters or gazettes), the internet (website or mailing list) and mobile phones.

In recent years, information systems using mobile phone support have continued to grow in most developing countries (Aker and Mbiti, 2010; Tadesse and Bahiigwa, 2015; Beza et al., 2018). Qualified as electronic information systems, they are increasingly instruments for promoting agricultural development in developing countries. Due to their high level of access, broad reach, good adoption rate and real-time interaction, mobile phones offer effective solutions to rural communication problems (Msoffe and Ngulube, 2016).
They effectively reduce the distance between individuals and institutions, facilitating the sharing of information and knowledge. Mobile phones are a global communication channel for rural communities, expanding the impact of established rural media, such as rural radio, and helping to make local content accessible to rural people and making rural services more efficient and profitable (Aker and Mbiti, 2010; Msoffe and Ngulube, 2016). Although the use of electronic information systems in agriculture is in its infancy, recent studies have indeed shown the potential of these information systems in agriculture. Kidole (2015) reports that these information systems have increased the gross profits of $90 \%$ of farmers in Moshi District in Tanzania. In the case of Ethiopia (Tadesse and Bahiigwa, 2015; Beza et al. 2018), it is of note that the information provided by mobile phones has allowed farmers to increase their yields. In Uganda, access to business information through electronic information systems has increased farmers' incomes by $16.5 \%$ to $36 \%$ (Marke, 2014). Subervie and Galtier (2014) show that in Ghana, farmers who have benefited from continuous information on market prices via mobile phone have been able to improve their average selling price of $12.7 \%$ for maize and $9.7 \%$ for groundnuts.

While the services offered by electronic information systems are important for generating efficiencies in production and improving farmers' incomes, they are not always adopted by farmers (Tadesse and Bahiigwa, 
2015; Duchaufour et al., 2016; Beza et al., 2018). The reasons seem subtle and go beyond the rational decisions traditionally advocated in the economic approach. In this sense, it is no longer the objective characteristics of the environment, as indicated in the standard economic approach, which are supposed to define the behaviour of the economic agent, but the type of knowledge held by the agent. But the individual can only have an incomplete and subjective knowledge of the environment in which he acts. This hypothesis reflects the fact that the individual is not looking for optimal solutions to solve the problems he encounters, but that he is content with accessible and satisfactory solutions (Bromley, 2006; 2008). In the case of agricultural innovations, Chambers et al. (1994) show that the farmer does not think in terms of adoption or rejection as researchers do. He seeks to know this novelty, its features, its advantages and disadvantages, then forms his own opinion of the new idea and determines the attitude to be observed: either adoption or rejection. In addition to understanding the premises of awareness of the services provided by electronic information systems, it is desirable to understand what would increase its degree of use by farmers. Often, public authorities have focused on stimulating awareness, the idea being that increased use will follow (Fall et al., 2015).

In Burkina Faso, the literature on the adoption of agricultural technologies is rich in theoretical concepts, and targeted studies on different types of technologies are abundant. However, minimal research has examined the factors affecting adoption of electronic information systems by rural actors. This study attempts to fill this gap by attempting to empirically analyse the factors that influence the awareness and use of services offered to grain farmers through these information systems. The grain farmers were chosen in view of the crucial importance of cereal crops in agriculture in Burkina Faso. Cereals occupy more than $75 \%$ of the annual area cultivated in Burkina Faso (MARHASA, 2016). A better understanding of the factors affecting the adoption of electronic information systems by farmers offers new opportunities for agricultural extension actors, agricultural professionals, information specialists and MIS management structures to design the most effective strategies for disseminating agricultural information.

The originality of this study exists at two levels. First, to our knowledge, there is no work on the adoption of electronic information systems by farmers in Burkina Faso. Thus, our work can provide an interesting basis for comparison with studies conducted in other parts of the world. Second, we highlight that the factors influencing the awareness of the services offered by electronic information systems are not the same as those influencing the use of these systems.

The following section provides a review of the literature that shows the challenge of farmers' access to information via the mobile phone and highlights the main theoretical determinants underpinning our analysis of the adoption of electronic information systems. The third section presents the methodological approach used. The method of collecting primary data from farmers and the Logit Sequential model used to analyse these data are exposed. The results of statistical analyses and the determinants of the awareness and use of electronic information systems are presented and discussed in the fourth section. Finally, we conclude by reflecting on the public policies to be implemented to increase the adoption of these information systems.

\section{LITERATURE OVERVIEW}

This section provides a review of the literature that shows the challenge of farmers' access to information via the mobile phone and highlights the main theoretical determinants underpinning our analysis of the adoption of electronic information systems.

\section{The challenge of access to information}

From an economic point of view, the performance of agricultural markets depends in particular on the quality of the flow of information between the various actors in the agricultural sectors (Aker, 2010; Duchaufour et al., 2016). Access to market information enables users to make better decisions about investing, producing, selling or buying. In fact, economic agents (traders, producers, public authorities) have information about agricultural markets (prices, quantities, quality) that is often incomplete, and sometimes false. In addition, asymmetries of information are common (De Janvry et al., 1991; Bullock et al., 2002; World Bank, 2009; Aker, 2010; Rashid and Minot, 2010; Siyao, 2012). Market information systems would help reduce information asymmetries and transaction costs (searches for information, verification of validity, etc.). MIS would lead to improved individual decisions and a rebalancing of forces between different actors.

The function of MIS is to collect information on markets and to disseminate this information to public (State) and private (producers, traders, consumers).

The first generation of MIS was managed by centralized public services that collated and processed grain price data and disseminated it in several media such as national radio, television, newspapers and news bulletins (Duchaufour et al., 2016). Most of them were funded by projects. Limited in terms of flexibility and innovation capacity, they had mixed results (Intereseaux, 2008). This system had several shortcomings, including delays in transmission, errors, few markets included, etc. Towards the end of the 1990s, many advances led to the emergence of the second generation of MIS. The appearance of mobile phones and the spread of the internet have offered many opportunities. Previously, the transmission of price data from the collection point to the central unit could take several days. Currently the information in "real time" can be delivered in a few hours. This has allowed for expanding product categories as well as considering different quality standards. Data are no longer pricerestricted, they also include other market-related information (local trade flows, imports / exports, sellers 'or buyers' contacts), production (meteorology, technical advice) or policy measures. (standards, regulations). The possibilities of real interactivity and contacts between buyers and sellers can be transmitted by individual offers. The use of mobile phones has increased to the point that this has attracted private entrepreneurs, who have set up 
market information services. Mobile telephones offer the possibility of interactivity, which represents an essential evolution: "push" systems, in which a standard information package is distributed to all users, can be replaced by "pull" systems, in which each user can choose the information they need from a wide range (either from individual requests or from individualized subscription systems). In addition, this interactivity allows MIS managers to control the information required and then adjust the service provided to meet the needs of users.

In Burkina Faso, both public information systems (MIS cereals of SONAGESS) and private information systems (MIS Afrique Verte of the NGO Afrique Verte, MIS CIC-B of the Interprofessional Committee of Cereals of Burkina) are registered. There are also sub-regional and international information systems (MIS RESIMAO, ESOKO). Private information systems are the most used. Farmers receive the information by SMS (Short Message Service). MIS management structures establish memoranda of understanding or information distribution contracts with national radio and television. There are two types of radio that are used by the agricultural world in Burkina Faso, namely: The National Radio, which covers a large part of the territory, and the community radios which are local radio stations that broadcast information in rural areas. MIS management structures use national television and private commercial televisions. The information is in French and in national languages (16 national languages are concerned). The broadcast is done at fixed times. For private SIMs, the content and the time of diffusion of the information are variable according to the types of contracts signed with radio or TV. Several MIS devices use the mobile phone. In recent years, electronic information systems have raised hopes in Burkina Faso because of the strong penetration of mobile telephony in rural areas. INSD (2015) indicates that 56\% of the rural population of Burkina Faso uses a mobile phone. In parallel with the explosion of mobile telephones, there is a very low level of commercial information among farmers (INSD, 2015). The challenge of access to information from electronic information systems is enormous, and it seems important to reflect on the possibilities of increasing access to agricultural information through such a system.

\section{Determinants of the adoption of a market information system}

The adoption of a technology is a process characterized by a certain level of heterogeneity, where it is very useful to understand the variables/factors that affect the process. A striking empirical observation regarding the adoption of new technologies is that there is usually a significant gap between the discovery of a new technology and its adoption. Early work by Schumpeter (1934) and Mansfield (1968) attributed the delay in adopting new technology to uncertainty about the nature of technological change. Studies on the adoption of technology indicate that the decision to use an innovation is a process in which different factors interact. Rogers (1995) pointed out that innovations perceived by farmers as having a greater relative advantage, compatibility with past experience and farmers' needs, a clear observability of results, an ease to be experienced and a reduced complexity would be adopted faster than other innovations.

Another set of factors that play an important role in the adoption process is related to the characteristics of the adopters. Researchers have found that men far outnumber women in the use of information technology (Ma et al., 2018). In several studies, education and age have also had positive effects on the adoption of electronic information systems (Velandia et al., 2009; Birba and Diagne, 2012; Carrer et al., 2017; Beza et al., 2018; Ma et al., 2018). According to these studies, the level of education has increased farmers' ability to process information, make decisions and acquire new information technologies. For age, there appeared two possible contradictory effects. On the one hand, older farmers were likely to have greater knowledge of the benefits associated with new information technology and find it easier to use this technology. On the other hand, older farmers were more conservative and less likely to use new technologies. It is therefore difficult to hypothesize for this variable. In addition, a number of researchers (Hollenstein, 2004; Carrer et al., 2017; Mothobi and Grzybowski, 2017) have shown that economic and financial factors, such as the farmer's income level and the cost of access to information technology, were important factors in the farmers' decision to adopt the technology. These researchers have shown that low income and a high cost of technology are barriers to the adoption of information systems. Another important factor that has emerged in the use of new information technologies is the size of the farm (Velandia et al., 2009; Tadesse and Bahiigwa, 2015; Mbanda-obura et al., 2017). Farmers with a large agricultural area were more likely to adopt new information technologies than farmers who cultivated a small area. It has also appeared in the literature that the perceived relevance of non-commercial benefits offered by technology has increased the likelihood of its adoption (Diekmann et al., 2009; Msoffe and Ngulube, 2016; Laraichi and Hammani, 2018). Other authors have also shown that those with limited previous experience in using short message service (SMS) were less likely to adopt electronic information systems (Zhou et al., 2010). Finally, some studies have found that institutional factors, such as agricultural extension and access to agricultural credit, positively affected the adoption of information technologies (De Janvry et al., 2015; Mbanda-obura et al., 2017; Carrer et al., 2017).

\section{DATA AND METHODS}

This section presents the methodological approach used. The method of collecting primary data from farmers and the Logit Sequential model used to analyse these data are exposed.

\section{Study areas and data collection}

Our sample comes from a field survey conducted between July and December 2017 by the International Cabinet of Economic, Environmental, Social and Spatial Expertise. This research office is a private structure that has existed since 2012 and has conducted several surveys and studies 
for the benefit of private institutions in Africa. It is based in Ouagadougou. The purpose of the survey was to collect primary data to build the capacity of grain producers for better market access. These data were collected from 210 farm managers, as well as heads of households. A semistructured survey questionnaire was prepared, and the investigators were trained for the occasion. Cabinet selected interviewers who spoke local languages from the areas studied in order to ensure that the respondents understood the questions. Since the Cabinet survey was a multipurpose survey, the questionnaire was organized around several areas of investigation, including the socioeconomic factors of farmers and the institutional and technological characteristics of farming. We worked at the farm level collecting information about the farm manager and the farm household. A two-stage random sampling procedure was adopted to obtain the total sample size. First, three rural areas were selected on the basis of the importance of cereal production (sorghum, millet and maize) and the presence of MIS management organizations. Sorghum, millet and maize are the main dry cereals produced and consumed in Burkina Faso. The selected study areas were Boulsa (North Central region), Koudougou (West Central region) and Toma (Boucle du Mouhoun region). In each zone, there are also representations of MIS management structures that disseminate information to producers. This distribution is valuable, and the cost depends on the diversity of information requested. In these areas, some farm managers benefit from information via their mobile phones, thanks to the NGO grant. Second, 70 farm managers were randomly selected from each of the three zones. These farmers were identified using the list made available by agricultural extension officers, and farmers' organizations helped to confirm it. The criteria for confirming information included transparency, confidentiality rules and the validity of the information provided. Regarding transparency, a protocol describing the survey methodology and the survey guide is available and accessible. The database is available. The research team consisted of several academics. Reconciling the information held by the agricultural extension services with that provided by the farmer organizations made it possible to judge the overall validity of the information available. The survey approach also respected the data confidentiality rules.

\section{Specification of the analysis model}

Several authors (Buis, 2010; Fall et al., 2015; Gichuki and Mulu-Mutuku, 2018) describe the adoption of an innovation as a process that goes through two stages or transitions. First, the individual seeks to know the service and its utility. This "awareness" phase is the starting point for any adoption process. The second phase is "use", in which the individual actually uses the services offered by the electronic information system. As part of our work, the decision tree comes in the form of a two-level choice problem. The division of the choices into subsamples is easily feasible, insofar as one can naturally distinguish the farmers who are aware the electronic information system and those who are not aware of them on the one hand, and, on the other hand, those who use it, and those who do not use it. Thus, if farmers are not aware of a service offered by this system, then they will not use it. On the other hand, if farmers are made aware, then they will have to choose between using it or not. The hierarchical structure of our model can be reproduced in the form of the decision tree (Figure 1).

Figure 1 shows a hypothetical process, which is to be described using a sequential logit model (Buis, 2011; Fall et al., 2015; Gichuki and Mulu-Mutuku, 2018). The sequential logit model consists of separate logistic regression for each step or decision on the subsample that is "at risk" of making that decision. The adoption process of electronic information systems is thus described by a sequential model with two transitions: awareness and use.

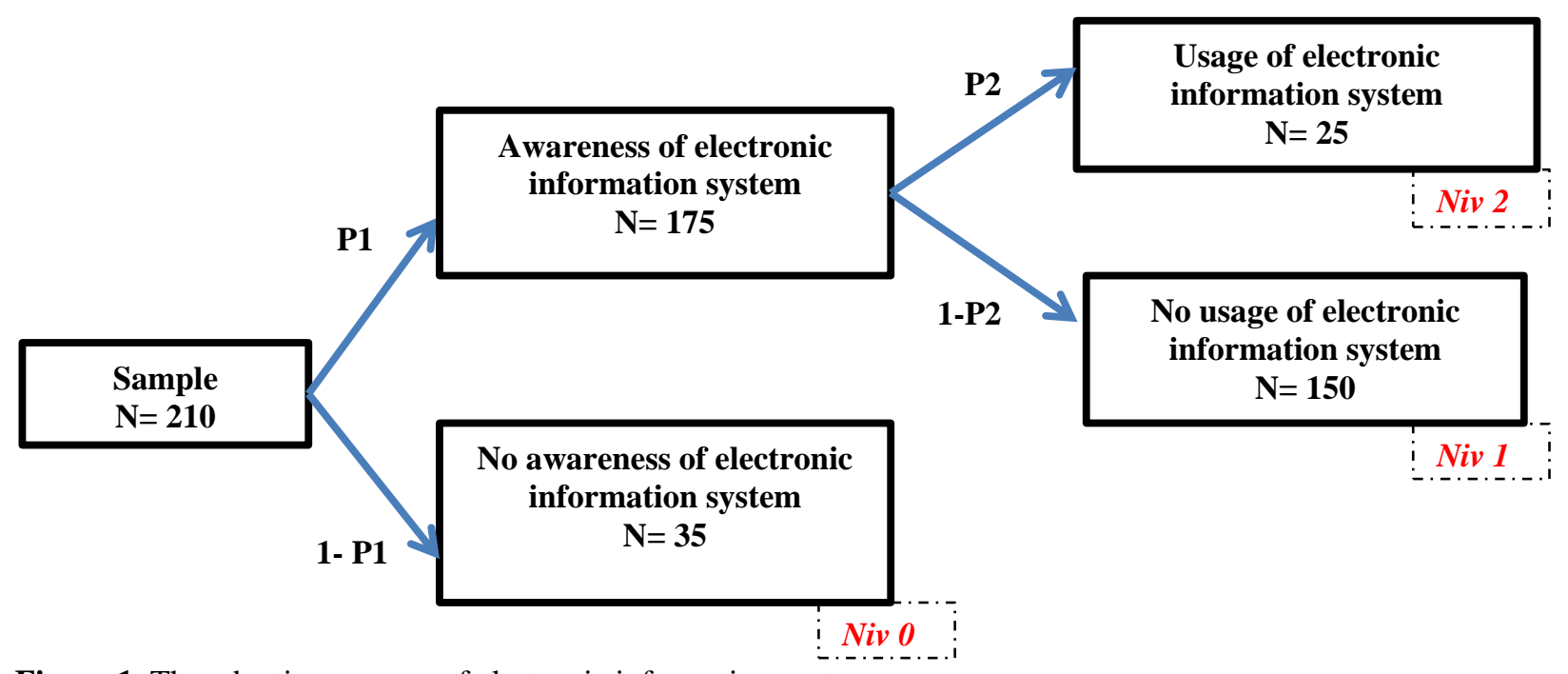

Figure 1. The adoption process of electronic information systems Source: Own elaboration 
The sequential logit model models the probabilities of passing these transitions. This is done by estimating a logistic regression for each transition on the sub-sample that is at risk, as in Eq. (1).

$p_{k i}=\frac{\exp \left(X_{k i} \beta_{k}\right)}{1+\exp \left(X_{k i} \beta_{k}\right)}$ if $P_{k-1, i}=1$

where $X_{k i}$ represents the characteristics of farmer i for step $\mathrm{k}$, and $\beta_{k}$ is a parameter vector to be estimated for step $\mathrm{k}$.

There are three levels in this process. At each level reached by the farmers, they are assigned a number, niv. For farmers who are not aware of the electronic information system, level 0 is assigned. For those who are aware of it but do not use it, level 1 is assigned, and for those who have used it, level 2 is assigned. The average level achieved for each farmer, given their socioeconomic characteristics, is determined by Eq. 2 .

$E(n i v)=\left(1-p_{1}\right) l_{0}+p_{1}\left(1-p_{2}\right) l_{1}+p_{1} p_{2} l_{2}$

where $l_{0}, l_{1}$ and $l_{2}$ are the farmer's gain at levels 0,1 and 2 , respectively.

The variation in a characteristic of the farmer affects the transition probability and is calculated by the formula (Eq. 3).

$$
\begin{aligned}
& \frac{\partial E \text { (niv) }}{X_{k i}}=\left\{1 \times \hat{p}_{1 i}\left(1-\hat{p}_{1 i}\right) \times\left[\left(1-\hat{p}_{2}\right) l_{1}+\hat{p}_{2} l_{2}-\right.\right. \\
& \left.\left.l_{0}\right]\right\} \beta_{1}+\left\{\hat{p}_{1 i} \times \hat{p}_{2 i}\left(1-\hat{p}_{2 i}\right) \times\left[l_{2}-l_{1}\right]\right\} \beta_{2}
\end{aligned}
$$

The marginal effect of the farmer's characteristics on the average level of the farmer is a weighted sum of the different levels (Eq. 4).

$$
\frac{\partial E(\text { niv })}{X_{k i}}=\omega_{1} \beta_{1}+\omega_{2} \beta_{2}
$$

The contribution of each level to reaching the adoption level of the technology is $\omega_{i} \beta_{i}$. The weights $\omega_{i}$ correspond to the risk of not passing the level $\times$ the variance of the indicator variable, whether or not the level $\times$ the farmer's gain passes if he passes the level. Thus, for the first level, the risk is [1], the variance is $\left[p_{1 i}(1-\right.$ $\left.p_{1 i}\right)$ ], and the gain if the farmer passes the first level is $\left[\left(1-p_{2}\right) l_{1}+p_{2} l_{2}-l_{0}\right]$. For the second level, the risk is $\left[p_{1 i}\right]$, the variance is $\left[p_{2 i}\left(1-p_{2 i}\right)\right]$, and the gain if the farmer passes the second level is $\left[l_{2}-l_{1}\right]$.

\section{RESULTS AND DISCUSSION}

Three categories of results are highlighted. First, the demographic, socio-economic and institutional characteristics of the farmers who participated in this study are presented. The information most frequently cited by farmers as being important and necessary, their assessment of the information they receive and their level of ownership of the access to information equipment are then exposed. The third result category deals with the impact of the farmer's socio-economic and institutional characteristics (sex, age, school years, household education, contact extension, years of mobile phone, farm size, technical assistance, perceived relevance of noncommercial benefits derived from information, access to agricultural financing) on the decision to adopt the electronic information system.

\section{Descriptive Analysis}

The descriptive statistics in Table 1 show that there is a significant gap between the proportion of farm managers who are aware of electronic information systems and the proportion that use them. Thus, despite the good awareness of these systems $(82.93 \%)$, few farm managers $(11.84 \%)$ use them. The question asked to farmers to create the "awareness" variable is this: when you think about agricultural market information systems, what supports come to mind? Table 1 presents the descriptive statistics of the explanatory variables of the sequential logit model. Table 1 also indicates that $90.05 \%$ of the sample is male. Such a result reflects the low proportion of farms headed by women. This scenario is understandable since, in rural areas, women can become heads of farms only when there is no longer a man of working age in the household. The average number of years of schooling for a farm manager is 1.86 years. This reflects the low level of schooling in rural Burkina Faso (INSD, 2015). However, $85.03 \%$ of farmers surveyed have at least one student in their household. The survey results also highlight that the average age of farm managers is 38 years, with a minimum of 17 years and a maximum of 86 years. There are, therefore, young farmers as well as relatively old farmers. In addition, the survey results reveal that almost all farm managers $(92.41 \%)$ are members of a professional organization. These organizations have the stated objectives of safeguarding and promoting the interests of all their members. The level of involvement of farmers in professional organizations can be seen as an indicator of their openness to the environment and information. In addition, the survey results show that the average size of farms is 3.31 ha. Farm size varies from 1.5 ha to 14 ha. The sample is therefore composed of farmers with very small agricultural sizes than those with relatively large areas. Such a disparity in farm size is observed at the national level (INSD, 2017). In addition, the average number of years of use of a mobile phone by farm managers is 2.28 years, with a minimum of 1 year and a maximum of 13 years. There are, therefore, relatively new mobile phone users, as well as farmers who have more experience in using these devices. The survey also shows that only $14.53 \%$ of farmers had access to agricultural finance, which came in the form of a credit or agricultural subsidy. In addition, $7.25 \%$ of farmers received technical assistance from MIS management structures. Finally, $14.79 \%$ of the farmers interviewed considered the information disseminated from electronic information systems to be relevant. 
Table 1: Variables considered in the econometric analysis model

\begin{tabular}{|c|c|c|c|}
\hline Variable & Description & $\begin{array}{l}\% \text { or } \\
\text { mean }\end{array}$ & SD \\
\hline Awareness & $\begin{array}{l}1 \text { if the farmer is aware of the electronic information system and } 0 \text { if } \\
\text { not }\end{array}$ & $82.93 \%$ & 0.443 \\
\hline Usage & $\begin{array}{l}1 \text { if the farmer uses the electronic information system to make his } \\
\text { decisions and } 0 \text { otherwise }\end{array}$ & $11.84 \%$ & 0.325 \\
\hline Sex & 1 if the farmer is male and 0 if not & $90.05 \%$ & 0.266 \\
\hline Age & Age of the farmer in years & 38 & 11.378 \\
\hline School years & Number of years of schooling of the farmer & 1.86 & 1.94 \\
\hline household Education & $\begin{array}{l}1 \text { if the household has an educated member outside the farm head } \\
\text { and } 0 \text { otherwise }\end{array}$ & $85.03 \%$ & 0.424 \\
\hline Organization & $\begin{array}{l}1 \text { if the farmer is a member of a professional organization and } 0 \\
\text { otherwise }\end{array}$ & $92.41 \%$ & 0.500 \\
\hline Extension contact & $\begin{array}{l}1 \text { if the farmer has contact with agricultural extension services and } 0 \\
\text { if not }\end{array}$ & $92.41 \%$ & 0.446 \\
\hline Technical assistance & $\begin{array}{l}1 \text { if the farmer has received technical visits from the MIS } \\
\text { management structures and } 0 \text { if not }\end{array}$ & $7.25 \%$ & 0.684 \\
\hline $\begin{array}{l}\text { Years of using mobile } \\
\text { phone }\end{array}$ & Number of years of mobile phone use by the farmer & 2.28 & 0.627 \\
\hline Farm size & Size of the farm & 3.31 & 3.151 \\
\hline $\begin{array}{l}\text { Access to agricultural } \\
\text { financing }\end{array}$ & 1 if the farmer has access to agricultural finance and 0 if not & $17.53 \%$ & 0.810 \\
\hline Relevant information & $\begin{array}{l}1 \text { if the farmer considers relevant the non-commercial benefits } \\
\text { offered by the electronic information system and } 0 \text { otherwise. }\end{array}$ & $12.79 \%$ & 0.369 \\
\hline
\end{tabular}

\section{The information needs of farmers}

Before attempting to understand the determinants of the adoption of electronic information systems, it is necessary to understand the type of information considered important and necessary for the decision-making of managers. The survey results shed light on these information needs. As shown in Figure 2, the most important information needs relate to the availability and conditions of use of inputs (seeds, fertilizers, plant protection products) and agricultural equipment $(85 \%)$, market prices (wholesale and retail) (80\%), the list of input suppliers $(76 \%)$, market accessibility conditions (76\%) and existing potential sources of financing $(70 \%)$. Similarly, half of the farm managers in the sample $(50 \%)$ mention the need for meteorological information and information on conservation techniques for agricultural products. Finally, information on market prices of imported agricultural products, transport opportunities and agricultural regulations are cited by $20 \%, 15 \%$ and $12 \%$ of farm managers, respectively. These results highlight that farmers have information needs related to the main constraints they face in the production, conservation and marketing of agricultural products. It is important to note that all of this information is available from MIS management structures.

In addition, the results of the survey reveal a high rate of nonsatisfaction about access to information among farmers (Figure 3). All the farmers interviewed feel that they do not receive the information they need. The reasons given are that information is not received in a timely manner $(79 \%)$, is not relevant $(75 \%)$, is fragmented $(62 \%)$ or is unreliable $(60 \%)$. The low frequency of information received and the difficult analysis of this information are also indicated by $50 \%$ of the farmers interviewed. When the farmer refers to information not received in a timely manner, he emphasizes the long delays in the information chain. However, when he refers to the low frequency of the information received, he emphasizes the low regularity and low updating of the data. Indeed, information can be obtained regularly by the farmer (e.g. the price variation) but not in time that would allow him to negotiate better his selling price. Similarly, information can be given at a given time, which can be useful for the farmer at this point in time (for example, the demand for agricultural products in different markets at harvest) but not regularly updated (e.g. lack of the same information in the dry season).

In summary, farm managers express the need for timely access to relevant, reliable and unfragmented information. We can notice that electronic information systems have the potential to meet such a need.

\section{Analysis of access to information equipment}

To access information, some tools are needed. It seemed useful to us to evaluate the level of possession of these tools by the farmers surveyed. The possession of a radio in the household is reported by the majority of farmers surveyed (97\%) (Figure 4). Almost all farmers (94\%) also reported that at least one household member has a mobile phone, $12 \%$ of farmers own a TV, and only $4 \%$ say they connect to the internet.

It appears that mobile phones as well as radio can be an appropriate channel for transmitting information to farmers. 


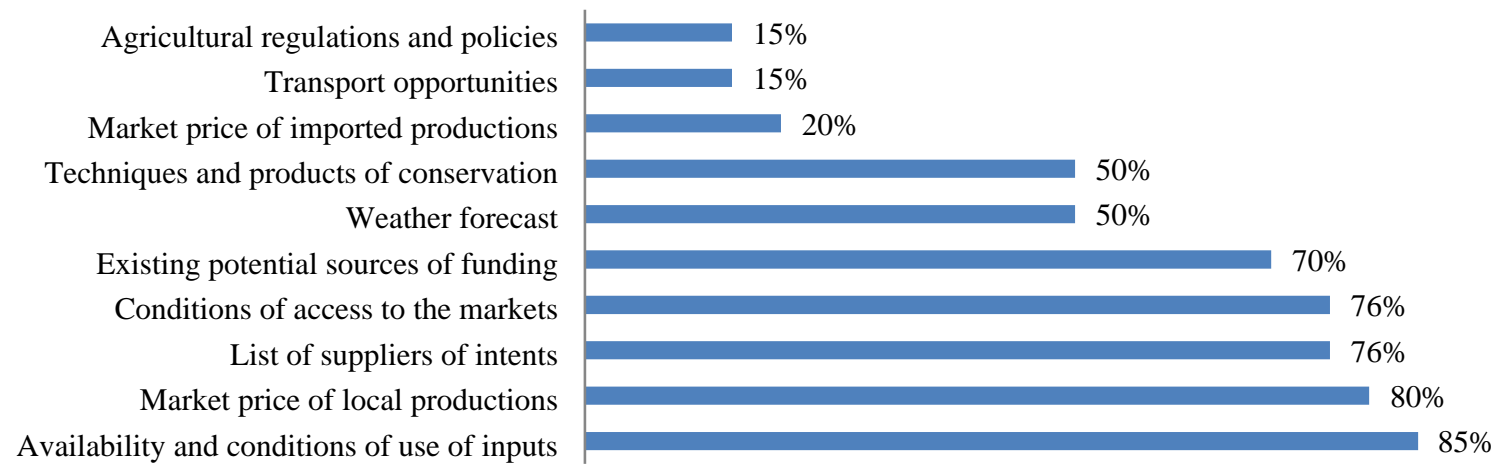

Figure 2. Information needs of farm managers

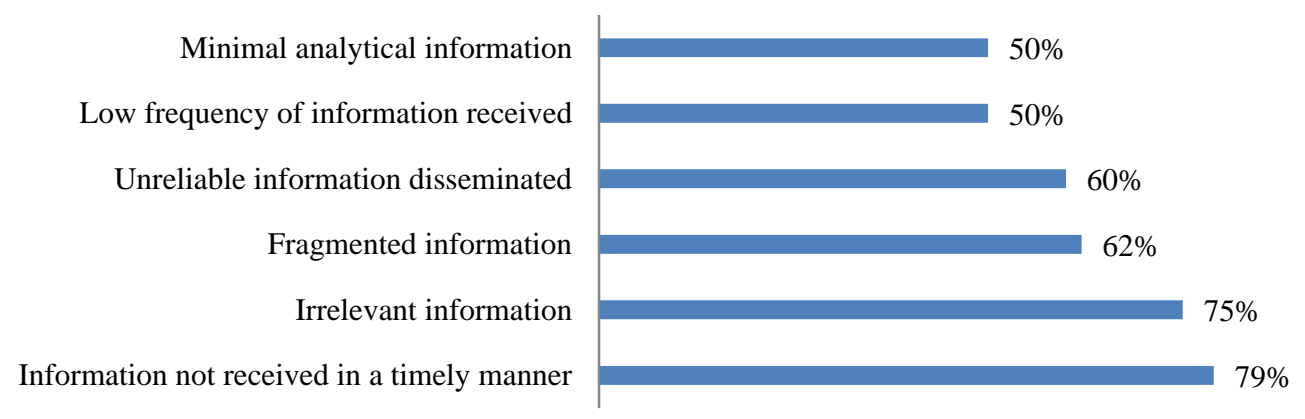

Figure 3. Reasons for nonsatisfaction with the information received by farmers

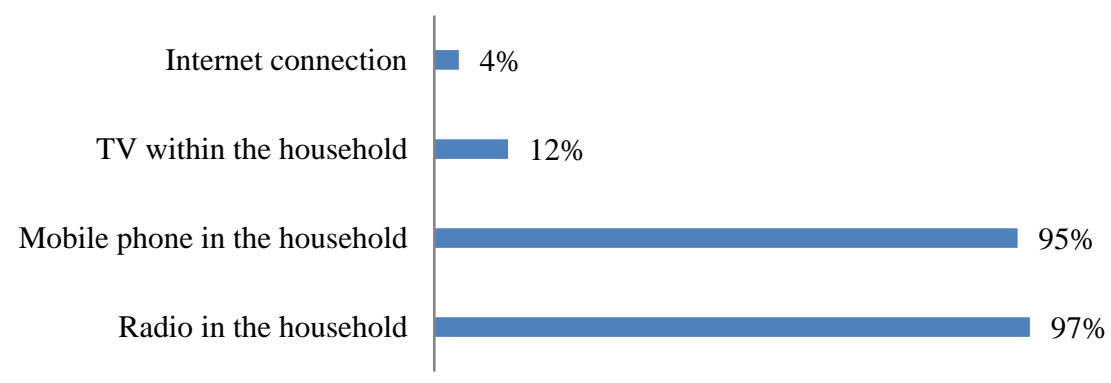

Figure 4. Access to information tools.

\section{Econometric results}

Table 2 presents the results of the logit sequential model estimation. In addition to the estimated parameters, the marginal effects of each independent variable on the dependent variable of the respective model are also presented. These effects show the variation in the dependent variable in response to small changes in an independent variable, all else remaining equal. The maximum likelihood ratio test rejects the null hypothesis that all coefficients are statistically equal to zero. The variable "membership in an agricultural professional organization" was removed from the estimate because it had a very strong correlation with the variable "agricultural extension". This strong correlation is understandable to the extent that farmers join farmers' organizations in order to access extension services and credit facilities. The variable "sex" was also removed from the estimate of the probability of using electronic information systems because no female farm manager in the sample used the services of these systems.

\section{Determinants of Awareness of Electronic Information Systems}

The results show that the most marked differences are apparent in the number of years of schooling of farm manager, the contacts with agricultural extension agents and the technical assistance of the agents of MIS management structures.

The results of this study indicate that farm managers with higher years of schooling are more likely to be aware of the services offered by electronic information systems. This result is in line with previous work (Velandia $\boldsymbol{e t}$ al., 2009; Carrer et al., 2017; Aklin et al., 2018; Beza et al., 2018; Ma et al., 2018). 
Table 2. Estimation of the determinants of awareness and use of the services offered by electronic information systems (marginal effects and standard errors in parentheses)

\begin{tabular}{|c|c|c|}
\hline Variable & $\begin{array}{l}\text { Awareness of an electronic } \\
\text { information system }\end{array}$ & $\begin{array}{l}\text { Use of an electronic } \\
\text { information system }\end{array}$ \\
\hline Sex & $\begin{array}{l}0.350 \\
(1.202)\end{array}$ & - \\
\hline Age & $\begin{array}{l}-0.089 \\
(0.132)\end{array}$ & $\begin{array}{l}0.127 \\
(0.112)\end{array}$ \\
\hline Age squared & $\begin{array}{l}0.001 \\
(0.001)\end{array}$ & $\begin{array}{l}0.001 \\
(0.001)\end{array}$ \\
\hline School years & $\begin{array}{l}0.093 \\
(0.127) * *\end{array}$ & $\begin{array}{l}0.447 \\
-(0.169)\end{array}$ \\
\hline Household education & $\begin{array}{l}0.027 \\
(0.210)\end{array}$ & $\begin{array}{l}0.058 \\
(0.206) * *\end{array}$ \\
\hline Extension contact & $\begin{array}{l}0.289 \\
(1.055) * *\end{array}$ & $\begin{array}{l}0.720 \\
(0.582)\end{array}$ \\
\hline Years of using mobile phone & $\begin{array}{l}0.198 \\
(0.396)\end{array}$ & $\begin{array}{l}0.029 \\
(0.462)\end{array}$ \\
\hline Farm size & $\begin{array}{l}0.030 \\
(0.078)\end{array}$ & $\begin{array}{l}0.061 \\
(0.123) * *\end{array}$ \\
\hline Technical assistance & $\begin{array}{l}0.529 \\
(0.937) * * *\end{array}$ & $\begin{array}{l}0.203 \\
(0.860)\end{array}$ \\
\hline Relevant information & - & $\begin{array}{l}0.204 \\
(0.709) * *\end{array}$ \\
\hline Access to agricultural financing & $\begin{array}{l}0.236 \\
(0.069)\end{array}$ & $\begin{array}{l}0.259 \\
(0.112)^{* * *}\end{array}$ \\
\hline Constant & $\begin{array}{l}1.563 \\
(2.896) * * *\end{array}$ & $\begin{array}{l}6.189 \\
(3.226) * *\end{array}$ \\
\hline $\begin{array}{l}\mathrm{N} \\
\text { Log likewood }\end{array}$ & $\begin{array}{l}210 \\
-426.37\end{array}$ & \\
\hline
\end{tabular}

Note: $* p<0.1 ; * * p<0.05 ; * * * p<0.01$

The marginal effect on the number of years of schooling shows that each year of schooling increases the probability of awareness of the electronic information system by $9.32 \%$ (this value is calculated for the mean values of the number of years of schooling). The major task of education is to actively involve individuals in selfeducation process and encourage their independence in learning process (Sagitova, 2014). It helps to develop flexible and adaptable thinking. In addition, technical assistance has a large marginal effect value (0.529), so probability of awareness of the electronic information system for a farmer from technical assistance is $52.9 \%$ higher, than average. The significant effect of this variable is also observed in Carrer et al. (2017), who explained that farm visits made by agents of MIS management structures increased farmers' awareness of the characteristics of electronic technologies, thereby enhancing farmers' confidence in these technologies. Equally important, contacts with agricultural extension services increase the probability of awareness of electronic information services. The estimated marginal effect of this variable shows that the probability of awareness of electronic information systems for a farmer through agricultural extension is $28.9 \%$ higher than the average. This result is in line with previous studies (Tey et al., 2017; Mbanda-obura et al., 2017), showing that such contacts are an important tool for information transfer that allows farmers to better know the availability and functionality of new technologies.

However, having experience using mobile phones does not bring awareness of electronic information services. The variable "Age" included in the model in linear and quadratic forms also does not affect the probability of awareness of electronic information systems. Similarly, variables such as sex, farm size and access to agricultural finance do not appear to be significant determinants in the early stage of the adoption of electronic information services.

\section{Determinants of the use of the electronic information system}

In the second stage of the adoption process (i.e., the actual use of the electronic information system), the presence of educated members in the household, the size of the farm, the perceived relevance of non-commercial benefits derived from information and access to financing appear to be significant determinants.

In contrast to previous work, the number of years of schooling of the head of household does not significantly influence the probability of the use of electronic information systems. However, having educated members within the household, which was not important for awareness of electronic information systems, now appears as a variable that significantly explains the use of these information systems. This result is in line with the findings 
of Tadesse and Bahiigwa (2015), who indicated that the presence of an educated child or spouse in the household allowed the household to adopt a new technology. The education of a member of the household can therefore generate positive externalities within the household by allowing it to adopt the electronic information system. This result is understandable to the extent that head-ofhousehold farmers, when out of school, tend to consult with a member of their household for reading written messages or letters. Farm size, which was not a determinant of awareness, also appears to be a significant explanatory factor of use. This result is consistent with the findings of Velandia et al. (2009) and Hollenstein (2004). The probability of using the electronic information system is proportionately higher for large-scale farms, demonstrating the advantage of scale for the adoption of these information systems. The marginal effect of this variable on the probability of use is $6.1 \%$. Under the assumption that a physical farm size corresponds to a high farm income, we can also assume that interest in the use of electronic information systems corresponds with high levels of agricultural income. Moreover, as expected, the question of the relevance of the information disseminated seems to arise for farmers. The perceived relevance of non-commercial benefits derived from information increases the probability of farmers using electronic information systems by $20.4 \%$ compared to the average. Our analysis has indeed confirmed that the farmer will adopt the electronic information system when the information disseminated is relevant to confer a certain social status or prestige in the community. This conclusion is in line with the results of several studies which show that some farmers are ready to adopt a technology if they find interests in terms of hierarchical position, safeguarding jobs, legitimacy and authority, power and recognition, or prestige and privilege (Msoffe and Ngulube, 2016, Waren et al., 2016, Taylor and Bhasme, 2018).In this sense, when relevant information is disseminated to farmers, they will be encouraged to use this information because of the noneconomic benefits they obtain from using this information. The other key factor that has a significant effect on the effective use of electronic information services is access to agricultural finance. When the farm manager has access to a credit or agricultural subsidy, his probability of using electronic information systems is $25.9 \%$ higher than average. Similar findings can be found in Carrer et al. (2017) who indicate that access to finance reduces farmers' budget constraints and facilitates investment in new technologies.

Given that farmers, on average, have few years of schooling, it was anticipated that agricultural extension and technical assistance from MIS management structures would influence the use of electronic information systems, but this is not the case in our estimation. This result implies that farmers will not simply adopt the technology because they have regular contact with agricultural extension agents or because they receive technical assistance from the MIS management structures. Neither age nor experience in the use of mobile phones is significantly associated with the use of electronic information systems.

\section{CONCLUSIONS}

This research helped to understand the factors that influence awareness of electronic information systems and their use by grain producers in Burkina Faso. The econometric results suggest that the number of years of schooling of farm managers, contacts with the agricultural extension agents and the technical assistance of the MIS management structures make farmers more aware of electronic information systems. With regard to the actual use of the services offered by these information systems, the presence of educated child or spouse in the household, a large sized farm, the perceived relevance of noncommercial benefits derived from the information disseminated and access to funding appear to be significant and positive determinants. This article clearly shows that the determinants of awareness of electronic information systems differ from those of the actual use of the services offered by these systems. This conclusion has strong implications in terms of public policies.

It is suggested that the different public and private actors work together to ensure that sufficient attention is given to each of the elements that enhance the awareness and use of the electronic information system. This requires that governments, MIS management structures, information providers and village leaders play a key role in this regard. The management structures of MIS will have to seek to better understand the specific information needs of different farmers before embarking on information dissemination activities. It is therefore necessary for these structures to carry out regular assessments of information needs and to ensure that the information disseminated is context specific. They will also need to ensure that capacity building programs are designed and implemented and that information resources are available

Finally, since rural infrastructure is vital for the provision of information services to farmers, it is important that governments give priority to this field. Improving rural infrastructure would enable the electronic information system to be fully exploited. The lack of reliable energy sources due to low electricity coverage and the lack of other basic services such as transport, make ICT connectivity in rural areas particularly difficult. Improving such infrastructure would allow the electronic information system to be fully exploited. Rural areas of Burkina Faso continue to be sparsely covered and are not considered as a viable business case by telecommunication operators. Recent growth of teledensity in urban areas, fuelled by mobile technology, has meant that the digital gap between rural and urban areas has widened. The quality of rural infrastructure projects is, however, crucial for economic development. We agree with the World Bank (2005) that effective public sector action is required, to establish a regulatory and legal framework that enables the rise of a vibrant innovative competitive private telecommunications and ICT services sector, and to institute selective efficient and transparent public subsidies with high social payoff but low financial returns. 
The results of our research are of great importance to policymakers, agricultural specialists, researchers and NGOs undertaking studies on the use of the electronic information system in rural areas of developing countries. The study may also be useful to the private sector, other information professionals and farmers in the areas selected in this research and Burkina Faso as a whole.

\section{REFERENCES}

AKER, J. C. (2010). Information from Markets Near and Far: Mobile Phones and Agricultural Markets in Niger. American Economic Journal: Applied Economics, 2(3): 46-59.

DOI:

http://www.aeaweb.org/articles.php?doi=10.1257/app.2.3 .46

AKER, J. C., and MBITI, I. M. (2010). Mobile Phones and Economic Development in Africa. The Journal of Economic Perspectives 24(3): 207-232. DOI: 10.1257/jep.24.3.207

AKLIN, M., BAYER, P., HARISH S. P., and URPELAINEN, J. (2018). Economics of household technology adoption in developing countries: Evidence from solar technology adoption in rural India. Energy Economics 72: 35-46. https://doi.org/10.1016/j.eneco.2018.02.011

BEZA, E., REIDSMA, P., POORTVLIET, P. M., BELAY, M. M., BIJEN, B. S., and KOOISTRA, L. (2018). Exploring farmers' intentions to adopt mobile Short Message Service (SMS) for citizen science in agriculture. Computers and Electronics in Agriculture 151: 295-310.

DOI:

https://doi.org/10.1016/j.compag.2018.06.015

BIRBA, O. and DIAGNE, A. (2012). Determinants of adoption of Internet in Africa: Case of 17 sub-Saharan countries. Structural Change and Economic Dynamics 23: 463-472.

http://dx.doi.org/10.1016/j.strueco.2012.06.003

DOI:

BROMLEY, D. W. (2006). Sufficient Reason: Volitional Pragmatism and the meaning of economic institutions, Princeton University Press.

BROMLEY, D. W. (2008). Volitional pragmatism. Ecological Economics, 68, 1-13. DOI : $\underline{10.1016 / \text { j.ecolecon.2008.08.012 }}$

BUIS, M. L. (2011). The consequences of unobserved heterogeneity in a sequential logit model. Research in Social Stratification and Mobility 29: 247-262. DOI: 10.1016/j.rssm.2010.12.006

BULLOCK, D. S., LOWENBERG-DEBOER, J., and SWINTON, S. (2002). Adding value to spatially managed inputs by understanding site-specific yield response. Agricultural Economics 27: 233- 245. DOI: https://doi.org/10.1016/S0169-5150(02)00078-6

CARRER, M. J., FILHO, H. M., and BATALHA, M. O. (2017). Factors influencing the adoption of Farm Management Information Systems (FMIS) by Brazilian citrus farmers. Computers and Electronics in Agriculture 138: 11-19.

DOI: http://dx.doi.org/10.1016/j.compag.2017.04.004

CHAMBERS, R., PACEY, A. and THRUPP, L. A. (1994). Les Paysans d'abord. Les innovations des paysans et la recherche agronomique, Paris, Karthala.

DAVID-BENZ, H., EGG, J., GALTIER, F., RAKOTOSON, J., SHEN, Y. and KIZOTO, A. (2012). Les systèmes d'information sur les marchés agricoles en Afrique subsaharienne. De la première à la deuxième génération, Collection Focales: 14, AFD, Paris.

DE JANVRY, A., FAFCHAMPS, M., and SADOULET, E. (1991). Peasant household behaviour with missing markets: Some paradoxes explained. Economic Journal 101: 1400-1417. DOI: $10.2307 / 2234892$

DE JANVRY, A., SADOULET, E., KYLE, E., AND DAR, M. (2015). L'adoption des technologies agricoles: quelles leçons tirer des expérimentations de terrain? Revue d'économie du développement 23(4): 129-153. DOI: 10.3917/edd.294.0129

DIEKMANN, F., LOIBL C., and BATTE, M. T. (2009). The Economics of Agricultural Information: Factors Affecting Commercial Farmers'Information Strategies in Ohio. Review of Agricultural Economics 31(4): 853-872. DOI: $\underline{10.1111 / J .1467-9353.2009 .01470 . X}$

DUCHAUFOUR, H., RAZAFIMBELO, T., RAKOTOARISOA, J., RAMAMONJISOA, B. and RAKOTONDRAVAO B. (2016). Recherche interdisciplinaire pour le developpement durable et la biodiversite des espaces ruraux malgaches. Application a differentes thematiques de territoire. Actes du projet FSP PARRUR «PArtenariat et Recherche dans le secteur RURal ». Antananarivo SCAC/PARRUR, Ed. MYE. p.400.

FALL, F-S., KY, Y., and BIRBA, O. (2015). Analyzing the Mobile-Banking Adoption Process among LowIncome Populations: A Sequential Logit Model. Economics Bulletin, Economics Bulletin, 35 (4): 20852103. https://halshs.archives-ouvertes.fr/halshs-01225149 FEWSNET (2017). Les fondamentaux du marché des denrées de base et du bétail au Burkina Faso. Famine Early Warning Systems Network (http://www.fews.net).

GEBREMEDHIN, B., and SWINTON, S. M. (2003). Investment in soil conservation in northern Ethiopia: the role of land tenure security and public programs. Agricultural Economics 29: 69-84. DOI: 10.1016/S01695150(03)00022-7

GICHUKIA, C. N. and MULU-MUTUKU, M. (2018). Determinants of awareness and adoption of mobile money technologies: Evidence from women micro entrepreneurs in Kenya. Women's Studies International Forum 67: 1822. DOI: https://doi.org/10.1016/j.wsif.2017.11.013

HOLLENSTEIN, H. (2004). Determinants of the adoption of Information and Communication Technologies (ICT), An empirical analysis based on firm-level data for the Swiss business sector. Structural Change and Economic Dynamics $\quad 15: \quad 315-342 . \quad$ DOI: 10.1016/j.strueco.2004.01.003

INSD (Institut National de la Statistique et de la Démographie) (2015). Enquête multisectorielle continue (EMC) 2014, Alphabétisation et scolarisation. Burkina Faso. p.370.

INSD (Institut National de la Statistique et de la Démographie) (2017). Annuaire Statistique 2016, Burkina Faso. p.65.

KIDOLE, V. V. (2015). Contribution of rural electrification to household income in moshi district, 
Tanzania. University of agriculture, Morogoro, Tanzania. p.59.

LARAICHI, S. and HAMMANI, A. (2018). How can information and communication effects on small farmers' engagement in groundwater management: Case of SAISS Aquifers, Morocco. Groundwater for Sustainable Development 7: 109-120. DOI: https://doi.org/10.1016/j.gsd.2018.03.007

MA, W., RENWICK, A., NIE, P., TANG, J., and CAI, R. (2018). Off-farm work, smartphone use and household income: Evidence from rural China. China Economic Review.

DOI:

https://doi.org/10.1016/j.chieco.2018.06.002

MANSFIELD, E. (1968). Industrial Research and Technological Innovation. Norton, New York.

MARHASA (Ministère de l'Agriculture, des Ressources Hydrauliques, de l'Assainissement et de la Sécurité Alimentaire) (2016). Stratégie de développement des filières agricoles au Burkina Faso. Burkina Faso.

MARKE, A. T. (2014). Climate-Resilient Agriculture and Food Security, New Network Capabilities to Solve Global Problems. Global Solution Networks.

MBANDA-OBURA, S. A., TABU, I. M., AMUDAVI, D. M., and OBURA, R. K. (2017). Determinants of choice of agricultural information sources and pathways among sorghum farmers in ndhiwa sub-county, western kenya. International Journal of Agricultural Extension 5 (1): 3949. http://www.escijournals.net/IJAE

MINTEN, B., STIFEL, D., and TAMRU, S. (2012). Structural transformation in Ethiopia: Evidence from cereal markets. IFPRI-ESSP II Working Paper 39: http://essp.ifpri.info/publications/\#sthash.0cb1gig3.dpuf. MOTHOBI, O., and GRZYBOWSKI, L. (2017). Infrastructure deficiencies and adoption of mobile money in Sub-Saharan Africa. Information Economics and Policy 40:

DOI:

http://dx.doi.org/10.1016/j.infoecopol.2017.05.003

MSOFFE, G. E. P., and NGULUBE, P. (2016). Agricultural Information Dissemination in Rural Areas of Developing Countries: A Proposed Model for Tanzania. African Journal of Library, Archives \& Information Science 26 (2): 169-187.

RASHID, S. and MINOT, N. (2010). Are Staple Food Markets in Africa Efficient? Spatial Price Analyses and Beyond. Food Security, Collaborative Working Papers, 58562, Michigan University.

ROGERS, E. M. (1995). The Diffusion of Innovations. 4th Edition, Free Press, New York, NY.

SAGITOVA, R. (2014). Students' self-education: learning to learn across the lifespan. Procedia - Social and Behavioral Sciences 152: 272 - 277. DOI : 10.1016/j.sbspro.2014.09.194
SCHUMPETER, J. A. (1934). The Theory of Economic Development: An Inquiry into Profits, Capital Credit, Interest, and the Business Cycle, Cambridge, MA: Harvard University Press.

SIYAO, P. O. (2012). Barriers in accessing Agricultural Information in Tanzania with a Gender Perspective: The Case study of small-scale sugar cane growers in Kilombero District. Electronic Journal of Information Systems in Developing Countries: 1-19. DOI: https://doi.org/10.1002/j.1681-4835.2012.tb00363.x

SUBERVIE, J., and GALTIER, F. (2012). Systèmes d'Information de 2ème Génération en Afrique Subsaharienne: Etudes d'impacts. CIRAD, INRA, AFD, CTA, p.76.

SUBERVIE, J., and GALTIER, F. (2017). L'information sur les prix agricoles par la téléphonie mobile: le cas du Ghana. <hal-01594670>.

TADESSE, G., and BAHIIGWA, G. (2015). Mobile Phones and Farmers' Marketing Decisions in Ethiopia. World Development (68): 296-307. DOI: http://dx.doi.org/10.1016/j.worlddev.2014.12.010

TAYLOR, M., and BHASME, S. (2018). Model farmers, extension networks and the politics of agricultural knowledge transfer. Journal of Rural Studies 64 : 1-10. DOI : https://doi.org/10.1016/j.jrurstud.2018.09.015

VELANDIA, M., LAMBERT, D. M., JENKINS, A., ROBERTS, R. K., LARSON, J. A., ENGLISH, B. C., and MARTIN, S.W. (2009). Factors Influencing Selection of Information Sources by Cotton Producers Considering Adoption of Precision Agriculture Technologies. Selected Paper prepared for presentation at the Agricultural \& Applied Economics Association 2009 AAEA \& ACCI Joint Annual Meeting, Milwaukee, Wisconsin.

WARREN, C. R., BURTON, R., BUCHANAN, O., and BINNIE, R. V. (2016). Limited adoption of short rotation coppice: The role of farmers' sociocultural identity in influencing practice. Journal of Rural Studies 45 : 175183.

DOI :

http://dx.doi.org/10.1016/j.jrurstud.2016.03.017

WORLD BANK (2005), Information and Communication Technologies for Rural Development : Issues and Options, Volume 1. Main Report and Annexes. Washington, DC. https://openknowledge.worldbank.org/handle/10986/831 $\underline{6}$

WORLD BANK (2009), Eastern Africa: A Study of the Regional Maize Market and Marketing Costs, Technical report, BM, Washington, D.C.

ZHOU, T., LU, Y., and WANG, B. (2010). Integrating TTF and UTAUT to explain mobile banking user adoption. Computers in Human Behavior 26: 760-767. DOI: $10.1016 /$ j.chb.2010.01.013 